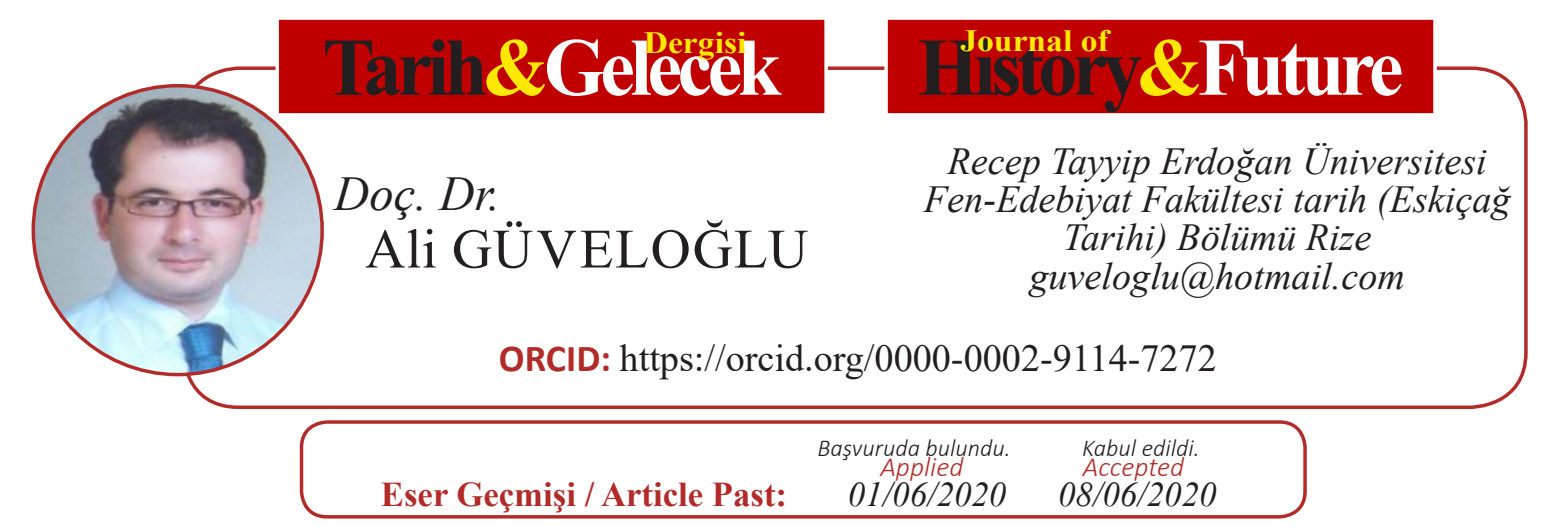

Araștırma Makalesi

DOI: http://dx.doi.org/10.21551/jhf.746625

Research Paper

Orjinal Makale / Orginal Paper

\title{
Cena Trimalchionis ve Eski Roma Mutfak Tarihindeki Yeri
}

\author{
Cena Trimalchionis and its Place in the History of Ancient Roman \\ Cusine
}

Öz

Bu çalışmada imparator Nero'nun şölenlerinin düzenlenmesinden sorumlu olan Petronius (Arbiter) Niger tarafindan M.S. 60-66 yıları arasında kaleme alındiğl düşünülen Satyricon adl romanın 26-78.8 paragrafları arasında yer alan son derece gösterişli ve abartılı bir akşam yemeğinin anlatıldı̆̆ Cena Trimalchionis adlı bölümü dönemin sosyopolitik gerçekleri ve yazarın üstü kapalı eleştirileri bağlamında incelenmiştir. Yazarın hizmet ettiği imparatora karşı düzenlenen başarısız bir suikast girişimine katılanlar arasında anıldı̆̆ için M.S. 66 yılında intihar ettiği biliniyor, bu nedenle eserin en geç bu tarihte yazllmış olduğu kabul edilir, ancak yayımlanma tarihi net değildir. Eserden günümüze yalnızca 141 paragraflık bir bölüm ile bazı fragmanlar ulaşmıştır, tamamının uzunluğu hakkında farklı görüşler öne sürülebilir, ancak kopukluk ve eksiklikler nedeniyle bu fikirlerin hiçbirisi tam doğru olarak kabul edilemez. Cena Trimalchionis olarak adlandırılan 52 paragraflık bölümde romanın ana karakterlerinin de katıldı̆̆ bir akşam yemeği anlatılır, bu anlatıda sunumlar gösterişli, yemekler abartıl, karakterler cahil ve zevksiz olarak yansitılır. Ana karakterlerin adı geçen akşam yemeğinden sıkılmaları ve oradan kaçmaya çalışmaları dikkate alındığında romanın ana konusunun yemek ve damak tadı üzerine kurgulanmadığı anlaşılır. Yine de Trimalchio gibi önemli bir karakterin yaratılması ve yemeğin bu karakter üzerinden yansıtılması yazarın yemekle içli-dışlı bir anlatımı tercih ettiği izlenimini uyandırır. Yapılan inceleme sonunda Cena Trimalchionis 'in dönemin sonradan görme azatlılarının incelmemiş damak zevklerini eleştirmek amacıyla yazıldiğ $ı$, metinde sık sık benzetmelere ve tezatlara başvurulduğu, gerçek ile gerçek dişı dünya algılarının karşılaştırıldı̆̆ı ve kendinden önceki bazı edebi eserlerle benzerlikler taşıliğ anlaşılmıştır.

Anahtar Kelimeler: Petronius, Satyricon, Cena Trimalchionis, Roma Akşam Yemekleri, Satire.

ATIF: GÜVELOĞLU Ali , "Cena Trimalchionis ve Eski Roma Mutfak Tarihindeki Yeri”, Tarih ve Gelecek Dergisi, 6/2 (Haziran 2020), s. (358-375) 


\section{Abstract}

In this study, we examined the novel, Satyricon which was written between 60-66 AD. by Petronius (Arbiter) Niger, whose ideas were effective for the arrangement of the feasts of Emperor Nero. The section titled Cena Trimalchionis between 26-78.8 paragraphs, which describes an extremely ostentatious and extravagant dinner was also examined in the context of the socio-political realities of the period and the implicit criticism of the author. As the author's name mentioned in an unsuccessful assassination attempt against the emperor he was forced to commite suicide in the year of 66 AD., so the work is considered to have been written at the latest in this year, but the date of publication is unclear. Only 141 paragraphs and some fragments of the novel have reached today, different opinions can be put forward about the length of the whole, but none of these ideas can be considered completely correct due to disconnection and deficiencies. In the 52-paragraph section called Cena Trimalchionis, a dinner with the main characters of the novel is also included, in this narrative, the presentations are showy, the dishes are exaggerated, the characters are ignorant and unappealing. Considering that the main characters get bored of the said dinner and try to escape, it is understood that the main subject of the novel is not based on food and taste. Nevertheless, the creation of an important character like Trimalchio and the introduction of food through this character gives the impression that the author prefers a narrative-intimate narrative with food. As a result of this study, it was understood that Petronius was written in order to criticize the unexamined palate tastes of Cena Trimalchionis of the period afterwards, and in the text, analogies and contrasts were used, and the real and surreal world perceptions were compared through the novel.

Keywords: Petronius, Satyrica, Cena Trimalchionis, Roman Convivum, Satire.

\section{Giriş}

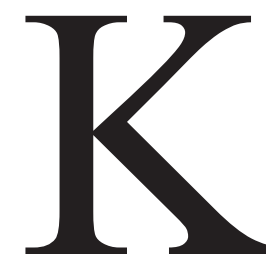

onunun günümüze olan uzaklığı, kaynakların az ve güvenilmez oluşu, günümüze kadar yapılan yorumların niteliği gibi nedenlerle Eski Romalıların yemek alışkanlıklarını araştırmak, bununla birlikte mutfak tarihlerini kurgulamak ve yazmak oldukça zorlu bir iştir. Bu makalede kimliği tartışmalı bir yazar olan Petronius Arbiter'in M.S. I. yüzyılın ikinci yarısına tarihlenen Satyricon adlı romanının 26-78.8. paragrafları arasında yer alan Cena Trimalchionis (Trimalchio'nun Akşam Yemeği) adlı anlatı servis edilen yemekler bakımından incelenecektir. Adı geçen roman günümüze tam olarak ulaşmamıştır, ulaşan kısımlardan anlaşıldığı kadarıyla dönemin "burjuvazisinin” incelmemiş alışkanlıklarına karşı eleştirel bir tarzın benimsendiği anlaşılır. Romanın ana karakterleri Enclopius, Ascyltus ve Giton' dur, bunların yanında adı geçen şölenin ev sahibi zengin azatlı Trimalchio ile karısı Fortunata romanın değilse bile en azından düzenlenen akşam yemeğinin ana karakteri sayılırlar. Trimalchio'nun arkadaşı Habinnas ve karısı Scintilla da yemeğin yan karakterleri sayılabilir. Enclopius ve arkadaşlarının adı geçen yemeğe katılmasına aracı olan Agamemnon zayıf fakat etkili bir karakterdir, şölenin diğer katılımcıları ise zayıf karakterler olarak kabul edilebilir. Son olarak yemek sırasında zaman zaman ortaya çıkan köleler, akrobatlar ve müzisyenler önemli bir anlatım unsuru olarak yer alırlar, fakat fikirsel 
anlamda bir önem taşımazlar. Romanın dili basittir, karakterler sokak dili konuşur, sıkça küfürlere başvururlar, şölenin sahibi süper zengin eski bir köle olan (romanda azatl, yani özgürdür) Trimalchio mal varlığıyla övünen kaba saba bir adamdır, konuklarına servis ettiği yiyeceklere bakılacak olursa Romalıların şölen düzenleme alışkanlıklarından haberdar olmadığ 1 anlaşılır, sürekli zengin içerikli et yemekleri sunmayı tercih ettiği, damak tadı zevklerinin yeterince incelmediği, tatlar arasında bir geçiş oluşturamadığ 1 anlaşılır. ${ }^{1}$ Petronius'tan günümüze ulaşan bölümler abartılı anlatımlar dışında olağanüstü bir şey içermez, roma dönemi kap-kacağı ve pazarları hakkında kısıtlı bilgiler sunar ancak tüm bu anlatıların 52 paragraftan oluşan Cena Trimalchionis' in gölgesinde kaldığ 1 bile söylenebilir.

\section{Petronius Kimdir?}

Romanın yazarı Petronius dönemin farklı yazarları tarafından farklı ön adlarla ve lakaplarla tanınmaktadır, bu nedenle kimliği hala bir tartışma meselesidir. Dönemin tanığı olarak yazan Cornelius Tacitus (M.S. 56-120) 61 yılı olaylarını anlatırken o yılın consullügünü ${ }^{2}$ Caesennius Paetus ile paylaşan Petronius Turpilianus adlı birinden ve bu ikilinin döneminde Britania' da çıkan isyanlardan söz eder. ${ }^{3}$ Fakat bu kişinin Satyricon'un yazarı olma ihtimali çok düşüktür, çünkü ne Tacitus ne de başka bir onun imparatora yakınlığından söz etmez. Tacitus'a göre 'eylemsizliği barış olarak isimlendirecek' kadar zayıf biri olan Turpilianus'un görevi aynı yıl içinde sona ermiştir. ${ }^{4}$ M.S. I. yüzyılın ikinci yarısı çok hızlı başlamıştı, ölen üvey babasının tahtına oturan Nero (54-68 arasında imparator) başlarda iyi bir yönetim sergilemişse de gittikçe dizginlenemez bir despota dönüşmüştü. Hükümdarlığının sonlarına doğru toplumun üst düzey fertleri tarafindan nefret edilen bir karakter halini almışt1. ${ }^{5} \mathrm{Bu}$ kapsamda Piso önderliğinde bir gurup M.S. 65 yılında imparator Nero'ya karşı başarısızlıkla sonuçlanan bir suikast girişiminde bulundu. ${ }^{6}$ Girişim ortaya çıkarıldıktan sonra imparator birçok kişiyi hemen öldürttü, aralarından soylu olanlara da intihar etmelerini bildirdi. İntihar etmek zorunda birakılanlar arasında stoac1 filozof L. Annaeus Seneca, onun yeğeni M. Annaeus Lucanus ve Satyricon'un olası yazarı Petronius da bulunuyordu. ${ }^{7}$ Bunlardan başka imparatorun sürgüne gönderip sonradan orada ölümlerini organize ettiği isimler arasında Cluvidienus Quietus, Iulius Agrippa, Blitius Catulinus ve Julius Altinus ile birlikte Petronius Priscus adlı bir kişi daha bulunuyordu. ${ }^{8}$ Böylece 65 yılında hayatta bulunan fakat hiçbir kaynakta yeme içme ve şölen düzenleme alışkanlıklarıyla ilişkilendirilmeyen bir Petronius daha listeden silinmiş oldu. Tacitus bundan başka Annaeus Mela, Cerialis Anicius, Rufrius Crispinus ile birlikte

1 Satyricon'un anlatım dili hakkında ayrıntılı bilgi için bkz. Graham Anderson, The Novella in Petronius, Latin Fiction: The Latin Novel in Context, Ed. Heinz Hofmann, London-New York, 2005, s. 45-49.

2 İmparatorluk döneminde Petronius soy adıyla bildiğimiz 6 aile vardır ve bunların yarısından fazlası consullük görevi yapmıştır. Bkz. Jonathan R. W. Prag-Ian D. Repath (Eds.), Petronius A Handbook, UK. 2009, s. 7.

3 Tacitus, Annales, XIV. 29. 1, Çev. J. C. Yardley, Ed. A. A. Barrett, Oxford, 2008.

4 Tacitus, Annales, XIV. 39. 2.

5 Edward Champlin, Nero Reconsidered, New England Rewiew, 19 / 2, 1998, s. 97 vd.

6 Nail W. Slater, Nero's Masks, The Classical World, 90 /1, 1996, s. 34 vd.

7 Seneca, Lucanus ve Petronius'un edebi kimliği hakkında bkz. Müzehher Erim, Latin Edebiyatı, İstanbul, 1987, s. 186-91.

8 Tacitus, Annales, XV. 71. 
hayatını kaybedenler arasında bulunan bir Petronius'tan daha söz eder. ${ }^{9}$

Bazen Gaius ön adıyla bazen de ön adı olmaksızın andığı bu Petronius'un gündüzleri uyuyup gecelerini zevk ve eğlenceyle geçirdiğini, herkes çalışkanlığıyla ün yaparken bunun şöhreti tembelliğiyle kazandığını, Bythinia valiliği (M.S. 62 yılında) ve consullük görevlerinde bulunduğunu, bu sayede imparatorun yakın çevresine dahil olduğunu ve imparator Nero'nun ondan fikir almadan eğlence düzenlemez hale geldiğini söyler. Aynı satırların devamında imparatorun yakın arkadaşı ve koruma muhafızı Tigellinus'la aralarının açılmasına sebep olan şeyin de onun bu özelliği olduğunu kaydeder. Nero'nun üzerinde etkili bir isim olması da işin cabası olmuştur. Fakat aralarındaki bu yakınlık uzun sürmemiştir, Tacitus'a göre Gaius ön adlı Petronius'un adı suikastçılarla birlikte anıldığ 1 için imparator onu bileklerini keserek intihar etmeye zorlamıştır. ${ }^{10}$ Aslında onun ve imparatorun akıl hocası Seneca'nın bu süreçte intihara zorlanmasında Tigellinus'un etkisi olduğu gerçeği göz ardı edilmemelidir. ${ }^{11}$ Tacitus bu sıra dışı Petronius'un kendi ölümünü bile zevkli hale getirmek için uğraştığını, kesilen damarlarını bir müddet sonra diktirip yeniden açtırdığını, ölmeden önce vasiyetinden imparatoru mahrum biraktığını ${ }^{12}$ ve sonradan sahte yazışmalarda kullanılmasın diye mühür yüzüğünü kırdırdığını ekler. ${ }^{13}$

Petronius'un imparator Nero ile olan yakınlığından ve ölümünden dönemin tanığ ansiklopedi yazarı Plinius (M.S. 23-79) da söz eder, birçok noktada Tacitus ile uyumlu bilgiler verse de Plinius onu Gaius değil Titus ön adıyla tanımakta ve Nero'yu mirasından mahrum bıraktığını vurgulamaktadır. ${ }^{14}$ Olayları dönemin görgü tanığı olarak kaleme alan bir başka yazar olan biyograf Mestrius Plutarkhos (M.S. 46-120) Moralia adlı eserinde Titus Petronius adlı birisinin Nero'yu nasıl alt ettiğini anlatırken Plinius ile hem isim hem de olay örgüsü bakımından ortak noktada buluşur. ${ }^{15}$ Fakat onun saray şölenlerinin düzenlenmesindeki rolünden söz etmez. Her üç yazarın söz ettiği Petronius'un da aynı kişi olduğu açıktır, ancak ya yazarlar ya da onların eserlerini kopyalayanlar Petronius'un ön adı hakkında yanılmış veya hata yapmış gibi görünüyor.

Tacitus Petronius'tan söz ederken Gaius'un yanı sıra "arbiter elegantiae"16 lakabını da kullanır. Bu sıfat ve imparatorun şölenlerini düzenleme yetkisini elinde bulundurması onu Satyricon'un yazarı olma yolunda diğer hepsinden bir adım daha öne çıkarır. Dönemin görgü tanı̆̆ı Tacitus'un ve onu takip eden diğer bazı yazarların anlatılarına bakarak M.S. 65 yılından hemen sonra intihara zorlanmış bulunan Gaius veya Titus ön adlı, Niger soyadlı ve

9 Tacitus, Annales, XVI. 17. 1.

10 Gareth Schmeling, Petronius and the Satyrica, Latin Fiction: The Latin Novel in Context, Ed. Heinz Hofmann, London-New York, 2005, s. 19.

11 Theresa N. Koper, Nero-Seneca and Tigellinus, Historia: Zeitschrift für Alte Geschichte, 28 / 3, 1979 , $347 \mathrm{vd}$.

12 İmparatorluk döneminde ileri gelenler vasiyetlerinde imparatora bir bırakarak onu onurlandırırlardı. Bu alışkanlık özellikle Caligula ve Nero dönemlerinde yaygın hale gelmişti.

13 Tacitus, Annales, XVI. 18-19.

14 Plinius, Historia Naturalis, XXXVII. 20, Çev. D. E. Eichholz, Cambridge vd., 2006.

15 Plutarkhos, Moralia, 60 d. Çev. H. Chernis, Ed. J. Henderson, Cambridge vd., 1976.

16 Seçkin damak üstadı; açıklamalar için bkz. Gareth Schmeling, The Satyrica of Petronius, The Novel in the Ancient World, Ed. G. Schmeling, Leiden-New York-Köln, 1996, s. 458. 
arbiter elegantiae lakaplı Petronius'un Satyricon'un yazarı olduğunu söyleyebiliriz. ${ }^{17}$ Diğer ön adların yazımındaki itilaf bir yazım yanlışı olarak kabul edilebilir, yazarın günümüzde de tanındığ 1 soy adı olan Arbiter ${ }^{18}$ ise onun resmi isimlerinden biri değil, mahlas adıdır. ${ }^{19}$ Tacitus'tan anlaşıldığı kadarıyla Titus (Gaius) Petronius Niger 62 yılındaki Bythinia valiliğinin ardından Seneca ve Lucanus ile birlikte imparator Nero'nun desteklediği edebiyatçıların arasına girmiş bu sayede edebiyat dünyasında bir yer edinmişti. ${ }^{20} \mathrm{Bu}$ hamlesi ona yazdığı eserine karakter transferi sağlamada yardımcı olmuş olabilir. Güçlü veriler sunulmasına karşın Satyricon'un yazarı hakkındaki veriler tam olarak netleştirilemediği için bazı araştırmacılar zaman zaman eserin adı bilinmeyen başka bir Petronius tarafından kaleme olabileceğini dile getirirler. ${ }^{21}$

\section{Satyricon Nedir?}

Satyricon veya Latince yazılış biçimiyle Satyrica konusunu günlük hayatın dinamikleri, sınıflar arası farklılıklar ve sıradan insanın hayatından alan Latince yazılmış bir roman olması nedeniyle önem taşır. Ancak esrin iddiası günlük yaşamdan izler taşımak değildir, derinlemesine bakıldığında yozlaşmışlıklara karşı yapılmış politik bir eleştiri görünümü kazanır. $^{22}$ Eserin tarihlemesine dair ipuçları bizzat metnin içinde aranmalıdır örneğin; 51.2. bölümde kullanılan Caesar sıfatı eserin en azından imparatorluk döneminde (M.S. 27-284 arası) yazıldığını ortaya koyar. 64.4'te imparator Caligula (M.S. 37-41 arasında imparator) döneminde yaşamış Apelles adlı bir tragedya oyuncusundan söz edilir, ${ }^{23}$ böylece eserin M.S. I. yüzyılın ilk çeyreğinden önceye gidemeyeceği fikri netlik kazanır. 52.3 ve 71.6 numaralı bölümlerde adı geçen Petraites imparator Nero döneminde (M.S. 54-68) yaşamış bir gladyatördü, bu ip ucuyla birlikte eserin tarihlemesi en azından aynı yüzyılın ikinci yarısına taşınmış olur. ${ }^{24}$ Metin bize daha başka ip uçları sunmaya devam eder, 73. 3. bölümde Trimalchio Nero döneminde yaşamış kitaro çalgıcısı Menecrates' in ${ }^{25}$ bir şarkısını mırıldanır, bu gönderme eserin Nero döneminde yazılmış olması ihtimalini güçlendiren ikinci önemli delil olabilir. Yukarıda Tacitus'un Petronius'un kişiliği ve ölümü hakkında yazdıklarına değinmiştik, eğer yazarın bahsettiği Gaius Petronius Satyricon'un yazarı ile aynı kişi ise eser M.S. 66 yılı sona ermeden önce yazılmış olmalıdır. Bu tarih birçok araştırmacı tarafindan terminus post quem olarak kabul edilmiştir. Petronius'un eserini belirli iki tarih arasında yazmış olduğu gerçeğine dayanarak bir de terminus ante quem oluşturma isteği doğması normal karşılanmalıdır.

17 Intihara zorlama uygulaması imparatorluk dönemi Roma’sında soyluları ölüme göndermek için tercih edilen bir yöntemdi, bkz. Schmeling, 1996, s. 459.

18 Bkz. Catherine Connors, Arbitrium and verse in the Satyrica and in Petronius redivivus, Latin Fiction: The Latin Novel in Context, Ed. Heinz Hofmann, London-New York, 2005, s. 55.

19 Prag-Repath, 2009, s. 6.

20 Kenneth F. C. Rose, The Date and the Author of the Satyricon, Netherlands, 1971, s. 10 vd.

21 Schmeling, 1996, s. 457.

22 Bret Boyce, The Language of the Freedmen in Petronius' Cena Trimalchionis, Leiden, 1991, s. 2.

23 Suetonius, De Vita Duodecem Caesaribus: Caligula, XXXIII, Çev. G. Özaktürk- F. Telatar, Ankara,2008.

24 Henry T. Rowel, The Gladiator Petraites and the Date of Satyricon, Transactions and Proceedings of the American Philological Association, 89, 1958, s. 15 vd.

25 Menecrates'in yaşamı hakkında bkz. Suetonius, De Vita Duodecem Caesaribus: Nero, XXX. 2 , Çev. G. Özaktürk-F. Telatar, Ankara,2008. 
Araştırmacılar Petronius'un başka eserlerden karakter transferi yapmış olabileceği fikriyle dönemin diğer edebi eserlerini incelemiş ve filozof Seneca’nın (M.Ö. 4-M.S. 65) Epistulae Morales'inde (Ahlaki Mektuplar) beliren son derece zengin, aynı oranda da görgüsüz Calvisius Sabinus adlı bir azatlı karakteri dikkatlerini çekmiştir. ${ }^{26}$ Seneca'nın yarattığı karakter kendisi okuyup bilgi edinmektense klasikleri okuyup ezberleyecek köleler satın alır, onların bilgisini kendi bilgisi sanırmış, kendisine bıraksan Homeros ve Troia kahramanlarının adını bile şaşırmadan sayamazmış. ${ }^{27}$ Aslında zengin ve cahil karakterler Eski Komedi döneminden beri tanınmaktaydı, fakat Roma'da eleştirel bakış açısının merkezine yerleştirilmeleri M.S. I. yüzyılda gerçekleşmiş gibi görünüyor. Petronius'un yarattığı Trimalchio karakteri de zenginlik ve görgüsüzlük bakımından Seneca’nın Calvisius Sabinus'undan geri kalmaz, yemek sırasında Troia savaşı kahramanları hakkında konuşmaya başladığında ${ }^{28}$ akla gelmez hatalar yapan Trimalchio Calvisius Sabinus karakterinin kopyası gibi görünür. ${ }^{29}$ İki karakterden hangisinin etkileyen-hangisinin etkilenen olduğunu söylemek zor, yine de bu benzerliği bir referans olarak kabul edersek Seneca'nın mektuplarını yayınlamaya başladığı M.S. 60-62 yılı Satyricon için terminus ante quem olarak önerilebilir. Dönemin eserlerine bir gönderme de 118. paragrafta bulunur. Bu noktada devreye giren Eumolpus şiir düzeni ve şiir yazarken kullanılması gereken kelimelerin neye göre seçilmesi gerektiği hakkındaki konuşmasına Lucanus'un iç savaşları konu alan şiirlerinden birini ekler;, ${ }^{30}$ Seneca'nın yeğeni Lucanus'un da Petronius'tan bir yıl önce (M.S. 65'te) ölüme gönderilenler arasında bulunduğunu, dolayısıyla şiirini de bu tarihten önce yazdığını düşünürsek Satyricon'un M.S. 65 yılına kadar yazılmış olduğunu anlarız. ${ }^{31}$ Aslında bu tarih Petronius için de olası ölüm tarihi olduğundan Lucanus'un şiiri mutlak bir tarihlemeden çok doğruluğu kabul edilen bir tarihin sağlaması olarak görülebilir. Görece kronolojinin oluşturduğu şemaya göre romanın M.S. 60-62 ile 65 arasında yazılmış olduğu bilgisine ulaşırız. Elbette Petronius'un bu işe Bythinia eyaleti valiliğini tamamlayıp, imparatorun şölenlerine yön verme görevine başlad1ktan sonra giriştiğini söyleyerek pergelin ucunu biraz daha daraltabilir ve eserin M.S. 63-65 yılları arasında yazılmış olabileceğini söyleyebiliriz.

Eserin adındaki -on takısı Yunancadan geçtiği için zaman zaman günümüze ulaşmamış Eski Yunanca bir romandan uyarlama olduğu fikri ortaya atılır, fakat Petronius'un romana verdiği gerçek adı bilmediğimizden bu tez sağlam bir temele oturtulamaz, karşı tezi savunanlar ise eserin adının Latince yazıma uygun biçimde Satyrica olabileceğini dile getirir ve bu ismi kullanırlar. ${ }^{32}$

26 Seneca, Ahlaki Mektuplar, XII. 8, XLVII. 1 vd. Çev. T Uzel. Ankara, 1992.

27 Seneca, Ahlaki Mektuplar, XXVII. 5.

28 Trimalchio'nun Homeros destanlarına ilgisi ve bilgi düzeyi hakkında bkz. Catherine Connors, Petronius The Poet, Cambridge, 1998, s. 84 vd.

29 Trimalchio'nun Troia kahramanları ve hatta tanrılar hakkındaki yalan yanlış ve çelişik bilgileri için bkz. Petronius, Satyricon, 59. 4-5.

30 Bkz. Petronius, Satyricon, 118-124; ayrica bkz. Costas Panayotakis, Petronius and the Roman Literary Tradition, Petronius A Handbook, Eds. Jonathan R. W. Prag-Ian D. Repath, UK. 2009, s. 50; Trimalchio'nun şiirle ilgisi hakkında bkz. Connors, 1998, s. 52 vd.

31 Lucanus'un şiirlerinin İç Savaştaki etkileri hakkında bkz. Randall Ganiban, Crime in Lucan and Status, Brill's Companion to Lucan, Ed. Paolo Asso, Lieden-Boston, 2011, s. 327 vd.

32 Schmeling, 2005, s. 20. 
Nero'nun M.S. 68'de bir darbeyle ortadan kaldırılmasından sonra Petronius'un da gözden düştügü ve pek okunmadığı söylenebilir, eserden ilk kez M.S. II. yüzyılın sonlarında yaşamış olan Terentianus Maurus söz etmiş, o da yanlış bir saptamayla Petronius'u kendi yaşadığ döneme tarihlemiştir. ${ }^{33}$ Bununla birlikte Deipnosophistai'nin konusuna oldukça uygunolmasınakarşın Athenaios'un neden Satyricon' danhiç sözetmediği anlaşılamamıştır. ${ }^{34}$ Romandan günümüze yalnızca XIV, XV ve XVI. kitaplar ile konumu belirlenememiş bazı fragmanlar ulaşmışır, kitapların hiçbiri eksiksiz değildir, metinde, cümleler arasında ve paragraf sonlarında boyutu belli olmayan kopukluklar bulunur. ${ }^{35}$ Gerçek metnin boyutu nedir, Petronius romanını bitirebilmiş midir sorularının cevabını bilemiyoruz, modern araştırmacılar elimize geçen fragmanlara bakarak romanın 20 veya 24 kitaptan oluşmuş olabileceğini söylerler. ${ }^{36}$ Elimize geçen metin bütünüyle daha önceki öykülerin hiçbirine benzemez, içerik olarak öykü Enclopius adlı bir gencin Giton adlı daha genç bir delikanlıya duyduğu eşcinsel aşk ve bu aşıkların arasında bir engel olarak duran Ascyltus adlı başka bir gencin giriştiği maceraları konu alır, bu açıdan bakıldığında Eski Yunan romanından etkilenmiş gibi görünür. ${ }^{37} \mathrm{Bu}$ makalede incelenecek olan Cena Trimalchionis adlı anlatı romandan günümüze ulaşan en büyük parçadır. Ancak kahramanların yemekten kurtulmaya çalışması ve buldukları ilk firsatta kaçarak uzaklaşmaları Petronius'un ası1 romanda eğildiği asıl ağırlık merkezinin yeme-içme adetleri olmadığı fikrini uyandırır.

\section{Cena Trimalchionis ile Ne Anlatılmak İsteniyor?}

Cena Trimalchionis' in nerede gerçekleştiği net olarak bildirilmez, ancak Campania'da bir kentte olduğu yazar tarafindan birkaç kez tekrarlanır. Fakat kentin statüsü hakkında verdiği bilgiler çelişiktir, birkaç kez koloni statüsünde bulunduğunu söylerken bir kez de aynı bölgedeki bir Yunan kenti olduğunu dile getirir. ${ }^{38}$ Konu hakkındaki tartışmalar devam etmekle birlikte Cumae veya Puteoli kentlerinin adı öne çıkmaktadır. ${ }^{39}$ Metin toplamda 52 paragraftır, bütünüyle incelendiğinde Trimalchio adlı zengin bir azatlının düzenlediği akşam yemeğinde orta düzeyde seçkin konuklara sunulan ultra lüks yiyecekler ile çeşitli eğlencelerin anlatısıdır. Yemekleri ultra lüks olarak tanımlamamın nedeni dönemi için oldukça fazla et içermesidir, Trimalchio konuklarına her serviste et ikram ederek zenginliğini ortaya koymaya çalışır. Metin farklı bakış açılarıyla farklı bölümlemelere tabi tutulabilir, bizim bakış açımıza göre 52 paragraflık metinde 7 düzeyli bir anlatı olduğu anlaşı1ır. ${ }^{40} 1$. kısım: 26-31. paragraflarda yemek alanına ulaşılır ve karakterler tanıtılır, 2. kısım: 31-36. paragraflar, çeşitli yiyecek-içecekler sunulur ve eğlenceler gerçekleştirilir. 3. kısım: 37-38.

33 Prag-Repath, 2009, s. 8.

34 Deipnosophistai hakkında ayrıntılı bilgi için bkz. Ali Güveloğlu, Antik Çağ’ın Damak Tadı Düşkünü Yazarlar1, Tarih ve Gelecek Dergisi, 5 / 2, 2019ª s. 256-59.

35 F. Gül Özaktürk, Satyricon, Ankara, 2003, s. 10.

36 Nail W. Slater, Reading the Satyrica, Petronius A Handbook, Eds. Jonathan R. W. Prag-Ian D. Repath, UK. 2009, s. 16-17; ayrica bkz. Schmeling, 1996, s. 459-61.

37 Tim Whitmarsh, Narrative and Identity in the Ancient Greek Novel, Cambridge, 2011, s. 160; ayrica bkz. Stephen Harrison, The Novel, A Companion to Latin Literature, Ed. S. Harrison, UK. 2005, s. 215.

38 Koloni statüsü için bkz. Petronius, Satyricon, 44.12,16; 57. 9; 76.10, Yunan kenti statüsü için bkz. 81. 3.

39 Romanın geçtiği coğrafya hakkında tartışmalar için bkz. Schmeling, 2005, s. 21.

40 Krş. Harrison, 2005, s. 214-15. 
paragraflarda Enclopius yanındaki konuklarla sohbet ederek çevredeki insanlar hakkında bilgi edinir. 4. kısım 41-46. paragraflar arasında Trimalchio ihtiyaç gidermek için dışarı çıkınca konuklar arkasından konuşur ve gevezelik yapar. 5. kısım 47-64. paragraflarda yemek sunumu ve eğlence devam eder, Niceros bir kurt adam hikayesi anlatır. 6. kısım 65-71. paragraflarda Habinnas gelir ve sohbetin merkezi olur, 7. kısım 72-78. paragraflarda Trimalchio Habinnas ile atışır, Enclopius ve arkadaşları yemeği terk etmek ister, Trimalchio konukları hamama götürür, Enclopius ile arkadaşları sıvışır.

Trimalchio'nun yemek düzeni yemeklerin bolluğu ve zengin hediyeler bakımından Makedonia'lı Karanos'un Dügün Yemeğinden, ${ }^{41}$ 41-46. paragraflardaki tartışmalar ve Habinnas'ın ziyareti kapsamında Platon'un Symposion'undan, ${ }^{42}$ konuklara ağır et yemeklerinin sunulması, ev sahibinin zenginliği, görgüsüzlüğü ve Nasideinius'un balık tabağının üzerine yıkılan tente anlatısıyla da Romalı şair Horatius'un (M.Ö. 65-M.S. 27) II. 8. numaralı saturasına konu olan Cena Nasidieni' den $^{43}$ izler taşır. Mesela hem Karanos'un dügün yemeğinin yazarı hem de Petronius Korinthos işi bronz tabaklara övgüler düzer, ${ }^{44}$ Satyricon'da konuklara bütün olarak pişirilmiş domuz ikram edilmesi Karanos'un aynı şekilde hazırlatıp gümüş mızraklara taktırarak konuklarına ikram ettiği Erymanthia domuzunu çağrıştırır. ${ }^{45} \mathrm{Bu}$ iki metin arasındaki en önemli ortak nokta ev sahibinin cömertliği ve yemeklerin çeşitliliğidir, konuklara dağıtılan hediyeler ve koku şişeleri, çalgıcılar ve cambazlar da başka ortak noktalar olarak kabul edilebilir. ${ }^{46}$ Öte yandan Habinnas'in Cena Trimalchio'ya gecenin ilerleyen saatlerinde hem de sarhoş bir biçimde gelmesi, Symposion'da Alkibiades'in aynı şekilde gelmesiyle karşılaştırılabilir. ${ }^{47}$ Elbette iki karakter arasında ciddi farklar bulunur, Alkibiades yanında kibar bir müzisyen kızla gelmiş, geç kaldığı için özür dilemiş, oturmak için izin istemiştir; buna karşılık Satyricon'un geç geleni Habinnas yemek odasına (triclinium) eşi Scillinta ile kaba saba bir giriş yapmış, en güzel yere kurulmuş ve hiç çekinmeden rahat davranışlar sergileyerek içki istemiştir. J. R. Morgan Petronius'un konuklarının bilgelik açısından Platon'unkilerin tam zıttı olduğunu düşünür, ${ }^{48}$ başka konularda ortak yanlar bulunabilir, fakat Satyricon bir bakıma idiotların toplantısıdır. ${ }^{49}$ Satyricon 54 'te cambaz çocuğun Trimalchio'nun üzerine

41 Athenaios, Deipnosophistai, IV. 128-131, Çev. S. D. Olson, Cambridge vd., 2016.

42 Her iki metinde genele yayılmış bir sohbet ortamı gözlenebilir, özel bir örnek olarak ev sahiplerinin yokluğunda konuşulanlar hakkında bkz. Platon, Symposion, 178a-180b, krş. Petronius, Satyricon, 44.

43 Bu saturada Fundanius Horatius'a bir gün önce katıldığg Nasidienus Rufus'un verdiği şöleni anlatır. Nasidienus'un konuklarına bütün domuz, tek tabakta toplanmış çeşitli kuş ve balıklar sunması Trimalchio'yu anımsatır. Bütün domuz ikramı için bkz. Horatius, Satire, II. 8. 8-10; balık ve kuş etlerini bir arada sunması hakkında bkz. 80 vd.; Yıkılan tente hakkında bkz. 55-60; Trimalchio'nun üzerine düşen akrobatla karşılaştırmak için bkz. Petronius, Satyricon, 54-55.

44 Karanos'un daveti için bkz. Athenaios, Deipnosophistai, IV. 128 b-c, krş. Petronius, Satyricon, 49.

45 Petronius, Satyricon, 40. 2, krş. Athenaios, Deipnosophistai, 130 b.

46 Karanos'un konuklara armağanı hakkında bkz. Athenaios, Deipnosophistai, 131 vd, Trimalchio'nun konuklarına ve hatta kölelerine dağıttığı armağanlar ve kokularla karşılaştırmak için bkz. Petronius, Satyricon, 40, 41, 50, 60 .

47 Platon, Symposion, 212 vd, Çev. Eyüp Çorakl1, İstanbul, 2007.

48 John Bodel, The Cena Trimalchionis, Latin Fiction: The Latin Novel in Context, Ed. Heinz Hofmann, London-New York, 2005, s. 33.

49 J. R. Morgan, Petronius and Greek Literature, Petronius A Handbook, Eds. Jonathan R. W. Prag-Ian D. Repath, UK. 2009, s. 38-39. 
düşmesi de Horatius'un Cena Nasidieni'sinde balık tabağının üzerine tente yıkılması olayını çağrıştırır. ${ }^{50}$ Cena Nasidienus ile Cena Trimalchio arasındaki tek benzerlik bu kadar da değildir. Her iki ev sahibi de sunduğu yemekleri anlatırken konukları biraz sıkar; ${ }^{51}$ her ikisi de alışı olunmayan biçimlerde yemek sunma konusunda 1 srarcıdır, ${ }^{52}$ her ikisi de türlü türlü şaraplar ikram etme konusunda cömerttir, ${ }^{53} \mathrm{iki}$ ev sahibi de kısa süreliğine yemek odasını terk etmek zorunda kalır, ${ }^{54}$ yine her ikisi de anlatının bir kısmında gözyaşlarına boğulurlar ${ }^{55}$ ve her iki şölenin sonunda da ana karakterler yemekten kaçarlar. ${ }^{56}$ İki metin de genel anlamda ev sahibinin incelmemiş damak zevklerine ve nobranlıklarına eleştirel bir yaklaşım sezilir.

M.S. I. yüzyılda Roma'da düzenlenen seçkin şölenler üç bölümden oluşurdu. Gustatio olarak adlandırılan ilk bölümde hafif atıştırmalıklar ve ballı şarap gibi yumuşak içecekler sunulur, konukların midesi ana yemeğe hazırlanırdı. Prima mensa olarak adlandırılan bölümde çeşitli et ve sebze yemekleri sunulur, bu bölüm yemeğin ana bölümü kabul edilirdi. Secunda mensa adlı son kısımda da çeşitli meyve, tatlı ve çerezler ikram edilirdi. Eski Roma davetlerinde Yunanlarınkinden farklı olarak şarap başlangıçtan sona kadar servis edilir ve yemekle birlikte tüketilirdi. ${ }^{57}$ Oysa Trimalchio'nun şölenindeki yemek servisi bu düzene uymaz, metinde konuklara içecekler hariç $12 \mathrm{kez}$ servis yapılır. Konuklar yemek salonuna alınıp soğuk sularla ayak bakımı yapıldıktan sonra ilk yemek olarak kocaman bir tepsinin içinde üzerine iki gözlü bir heybe asılmış olan Korinthos sıpası servis edilir. Heybenin bir gözünde yeşil, diğer gözünde siyah zeytin doludur, sıpanın üzerine iki büyük tabak kapak gibi kapatılmış ve tabaklar bir kulpla bağlanmıştır, kulpun üzerine de ballı kakırcalar dizilmiştir, ayrıca ete gümüş bir ızgaranın üzerinde kaynayan soslar eşlik eder. ${ }^{58}$ Görüldüğü kadarıyla bu ağır yemek bir gustatio, yani başlangıç olmaktan çok uzak, ağır bir yemektir, hatta genel anlamda değerlendirecek olursak bu tarz bir yemek herhangi bir şölenin prima mensasında sunulmak için bile ağır sayılabilir. ${ }^{59}$ İkinci olarak tahtadan oyulmuş bir tavuk maketinin altında tavus kuşu yumurtaları sunulur, aslında sunulan şey yumurta değildir, yumurta şekli verilmiş yağlı hamurun içi açılınca yumurta sarısı ve biber sosuna bulanmış bir ötleğen kuşu çıkar karşılarına, görüntüsü gerçekçi olmalı ki Enclopius yumurtayı açıp içinde sarı bir şeyler görünce yumurtasından civciv çıkacağından korkmuş, bir ara elindeki hamuru atmaya niyetlenmiştir. ${ }^{60}$ Aslında yumurta gustatio bölümünde sunulan ikramlıklardand1, fakat burada sunulan şey yine ana yemek olmaya yakın bir et yemeğidir.

50 Horatius, Satire, II. 8. 55-60; ayrica bkz. Panayotakis, 2009, s. 51.

51 Horatius, Satire, II. 8. 44-53, krş. Petronius, Satyricon, 39; ayrıca bkz. Courtney, 2001, s. 89.

52 Horatius, Satire, II. 8. 26-30, krş. Petronius, Satyricon, 33. 4-8, 69. 8-70. 3

53 Horatius, Satire, II. 8. 16 vd., krş. Petronius, Satyricon, 34. 6-8, 48.1

54 Horatius, Satire, II. 8. 76-78, krş. Petronius, Satyricon, 41. 9.

55 Horatius, Satire, II. 8. 58 vd., krş. Petronius, Satyricon, 72. 1; ayrıca bkz. Courtney, 2001, s. 121.

56 Horatius, Satire, II. 8. 93-95, krş. Petronius, Satyricon, 78. 8.

57 Ali Güveloğlu, Antik Çağ’da Beslenme ve Damak Tadı, İstanbul, 2018, s. 39.

58 Petronius, Satyricon, 31.

59 Romalıların I. yüzyıldaki beslenme düzeni coğrafyanın etkisiyle belirlenmişti, özel davetler dışında ağır et yemekleri nadiren tüketilirdi, genel izlenim hakkında ayrıntılı bilgi için bkz. Andrew Dalby, Empire of Pleasure, 2009, London, s. 25 vd. 
Üçüncü yemek tam bir görsel şölen niteliği taşır. Çünkü yuvarlak bir servis tepsisine 12 burç yerleştirilmiş, her bir burcun üzerine de o burcu temsil eden yiyecekler yerleştirilmiştir. Mesela koç burcunun üzerinde nohut, boğa burcunun üzerinde sı̆̆ır eti, ikizler burcunda bir çift böbrek, aslan burcu görselinin üzerinde de Afrika inciri bulunur, diğer burçların üzerinde de konuya uygun düşen başka yiyecekler yerleștirilmiştir. Bu yemeğe eşlik eden Mısırlı bir çocuk da gümüş bir ızgaradan ekmekler dağıtmaktadır. Konuklar, özellikle de Enclopius bu vasat yemek karşısında hayal kırıklı̆̆ına uğrarlar, Trimalchio tam bu sırada devreye girerek bu yediklerinin yemeğin sosu olduğu dile getirip gerçek yemeğin servis edilmesini ister. ${ }^{61}$ Dördüncü sıradaki yemek Trimalchio'nun asıl yemeğidir. Metinde kopukluk olduğu için yemeği tam olarak anlatmıyor, ancak kalan kısımlara bakılınca bir önceki gibi görsel yönden zengin bir yemek olduğu anlaşılıyor. Yemek aslında bir önceki burçlar tepsisinin altında salonda bulunuyormuş, bu yemek bitirildiğinde Trimalchio'nun isteğiyle dört dansçı odaya girip üstteki servis tepsisini alınca yeni bir tabak ortaya çıkmış. Alttaki tabakta semiz kuşlar, dişi domuz karnından yağlı bir parça ve tüylü kanatlarla uçan at pegasusa benzetilmiş bir tavşan varmış, metin burada kopukluğa uğradığından tabakta daha başka neler olduğunu öğrenemiyoruz, kopukluktan sonra üstteki bir oluktan kanalda yüzer gibi görünen balıkların üstüne soslar döküldüğü anlatılır. Yemeğin görseli çok iyi kurgulanmış olmalı ki tüm konuklar ve köleler hep birlikte alkışlamaya başlamışlardır. ${ }^{62}$ $\mathrm{Bu}$ yemekten sonra Enclopius daha fazla yiyememiş, bir şeyler öğrenmek amaciyla etrafındakilerle sohbet etmeye başlamıştır. Sohbet sırasında Trimalchio ve karısı Fortunata hakkında bilgiler öğrenir, özellikle ev sahibinin malvarlığı bu bölümde anlatılır. ${ }^{63}$

Bir süre sonra ortaya başka bir ana yemek getirilir. Bu gelen başında özgürlük tacı bulunan kocaman bir domuzdur, bütün olarak pişirilmiştir, dişlerinden sarkan sepetlerin birinin içine kuru, diğerininkine de taze hurmalar yerleştirilmiştir ${ }^{64}$ Hamurdan yapılmış yavru domuz şeklinde ekmekler ise annelerini emer biçimde yerleştirilmiştir, bunlar başlangıçta bir işe yaramazmış gibi görünse de aslında tüketilmek üzere hazırlanıp domuzla birlikte pişirilmiş ve Trimalchio'nun emriyle konuklara verilmişler. Ancak asıl sürpriz ana yemek olarak hazırlanmış domuzun karnı yarılınca ortaya çıkar, çünkü içine canlı ardıç kuşları yerleştirilmiştir, bunlar etrafta uçuşmaya başlayınca köleler tarafından yakalanıp konuklara armağan olarak verilmiş. Domuzun başındaki özgürlük tacı bir önceki günkü akşam yemeğinde yenmediği için Trimalchio tarafından taktırılmış, çünkü konuklar ona özgürlüğünü vermiş miş ${ }^{65}$ Bir gün önceki yemeğin konuklara sunulması ilginçtir, özellikle Trimalchio gibi gösterişi seven birinin alışkanlığına benzemez, ancak yazar burada yemeğe değil domuzun başındaki özgürlük tacına dikkat çeker, çünkü bu taç servis sırasında güzel sesiyle şarkı söyleyen bir köle çocuğa verilmiş, çocuk böylece özgürlüğünü kazanmıştır. Yemekte dikkat çeken ikinci unsur bütün domuzun karnı açılınca havaya uçuşan kuşlardır, yemek bir önceki günden kalmıştı, bu kadar uzun süre canlı kalamayacaklarına göre

\footnotetext{
61 Pertonius, Satyricon, 35.

62 Pertonius, Satyricon, 36.

63 Schmeling, 1996, s. 465 vd.

64 Domuzun bütün olarak pişirilmesi Eski Yunan edebiyatında Yeni Komedi olarak adlandırılan oyunlarda sık rastlanan bir anlatımdır, bkz. Schmeling, 1996, s. 466; bu gelenek Roma'da ilk kez Cato'nun consullük yaptığı (M.Ö. 118) yıl uygulanmıştır, bkz. Plinius, Historia Naturalis, VIII. 78. 210. 
kuşlar servis yapılmadan hemen önce o akşam konulmuş olmalılar. Üçüncü konu ise Petronius'un daha başka yerlerde de karşımıza çıkan sıra dışı sunum biçimleridir, yazar görünmeyen gizli ögeleri açığa çıkararak sürprizler yapıp okuyucuyu şaşırtmayı sever. Altıncı sırada sunulan yemek beşincinin neredeyse aynısıdır, ancak bu sefer konuklar için hemen o akşam hazırlanır, ev sahibi konuklara seçim yapmaları için canlı domuzlar getirtir ve seçtiklerini aşçıların hazırlamasını emreder, kısa süre sonra ortaya bütün olarak pişmiş kocaman bir domuz getirilir. Trimalchio konuklarına bir oyun hazırlamıştır, aşçının hayvanın içini temizlemeyi unuttuğunu söyler, konuklar bu durum karşısında iğrenirler de belli etmezler, aşçı odaya getirtilir ve iyice azarlandıktan sonra pişirmeden önce yapması gereken şeyi yapması istenir, domuzun karnı temizlenmek üzere açıldığında etrafa pişmiş sosisler ve salamlar dağglır. ${ }^{66}$ T1pkı bir önceki yemekteki gibi görünmeyen bir ögenin açığa çıkarılmasıyla konuklar hoşnut kalırlar. Şimdiye kadar sunulanların hepsi de ağır et yemekleridir ve yemeğin prima mensa adı verilen kısmına hitap eder, oysa ilk sunumların hafif atıştırmalıklar olması gerektiğine yukarıda değinmiştik.

Bundan sonra birdenbire yedinci yemek olarak konuklara içi safranlı sosla doldurulmuş çörekler ve yemişler sunulur. Metin kopuk olduğu için tabağın tam olarak nasıl biçimlendirildiğini anlayamıoruz, ancak tepsinin ortasında Priapos ${ }^{67}$ yontusu şeklinde pişirilmiş bir hamur işi bulunduğu, çöreklerin ve öteki şeylerin de bu yontunun kucağına yığıldığı anlaşılıyor. ${ }^{68}$ Enclopius ve öteki konukların bu ikramlıkları çantalarına doldurması şaşırılacak bir uygulama değildir. Şölenlerde konuklar kendilerine verilen ikramları yanlarında götürebiliyorlard $1{ }^{69} \mathrm{Bu}$ ikramdan sonra çeşitli eğlenceler ve akrobat gösterileri düzenlenir, bu sırada konuklar sohbet edebilir ve içkilerini yudumlayabilirler. Sekizinci yemekte konuklara besili tavuklar ikram edilir, Trimalchio bunların kemiksiz olduğunu söyleyerek konukları yemeye zorlar, ancak Enclopius artık midesinin yemek almadığını ve tiksindiği için yemekte zorlandığını söyler, ${ }^{70}$ çörekten sonra yeniden et yemeği sunmak pek alışıldık bir durum değildir, yani Trimalchio uygun olmayan biçimde secunda mensadan sonra yeniden prima mensaya ait yemekler sunar. Ardindan ev sahibi meyve getirilmesi emredince köleler masaları toplayıp etrafı temizler ve içeriye meyve taşırlar, Trimalchio meyveler getirilmiş olmasına karşın lezzetli bir şeyler varsa yine de getirilmesini ister.

$\mathrm{Bu}$ istek üzerine onuncu sırada servis edilen yemek içerik bakımından biraz karışıktır, çünkü Trimalchio'nun emri üzerine hem tatl1-meyve hem de et yemeği bir arada sunulmuştur. Bir kere hamurdan yapılmış ve içlerine findıkla kuru üzüm doldurulmuş ardıç şeklinde tatlılar bulunur masada, yanındaki tabaklarda da üzerine dikenler saplanarak deniz kestanesine benzetilmiş ayvalar dizilmiştir. ${ }^{71} \mathrm{Bu}$ tatlı tabağına hiç ara vermeden getirilen yemek Enclopius tarafından iğrenç bulunur, çünkü masaya etrafına türlü balık ve kuşlar

66 Pertonius, Satyricon, 49.

67 Aphrodite ile Dionysios’un oğlu olduğu söylenen bağ ve bahçe tanrısıdır, Lampsakos (Lapseki) ve adalar bölgesinde yaygın tapınımı görülür. Bereketi temsil ettiği için abartılmış erkeklik organıyla tasvir edilirdi. Anlatıda Priapus heykelinin yeri hakkında bkz. Emily Gowers, The Loaded Table: Representations of Food in Roman Literature, Oxford, 1993, s. 117.

68 Pertonius, Satyricon, 60.

69 Athenaios, Deipnosophistai, 130 b.

70 Pertonius, Satyricon, 65.

71 Pertonius, Satyricon, 69. 
dizilmiş besili bir kaz getirilir, ayrıca sonradan Trimalchio'nun yaptığı açıklamadan anlaşıldığı kadarıyla bunlar gerçek kuş ve balık bile değildir, kaz dahil hepsi de maharetli aşçı tarafından pişmiş domuz etinden biçimlendirilerek yapılmıştır. ${ }^{72}$ Dahası aşçısının aynı şekilde enva1 biçimde yiyeceği taklit edebileceğini dile getirir görgüsüz ev sahibi. Son sirada yine Roma yemek geleneklerine uygun olmayan biçimde midye ve salyangozlar ikram edilir, yemek sunumu daha öncekiler gibi beklenmedik bir görsel şovla başlar. Boyunlarına testiler takılı durumda bulunan köleler bir kurgu içinde birbirleriyle kavgaya tutuşurlar, bu sırada midyeler etrafa saçılır, başka köleler de bunları toplayıp konuklara dağıtır, bu sırada aşçı sunumu zenginleştirmek için gümüşs ızgaralar üzerinde salyangozlar sunar. $^{73}$ Trimalchio'nun yemek odasındaki ikramları bu kadardır, sirada sicak hamam keyfi yer alır, ancak Enclopius ve arkadaşları hamamda çıkan hengameden yararlanarak oradan uzaklaşırlar. ${ }^{74}$ Yemek boyunca konuklara içki dağıtılır, zaman zaman köleler etrafı toparlamak için odaya girebilir veya müzisyenler-akrobatlar gösterilere başlayabilirler, aşçılar, köleler derken yemek salonu her zaman hareketli ve gürültülüdür.

Kurgu içinde her okur kendine göre önemli yanlar bulup vurgulayabilir, bu çalışmada yazarın dikkatini çeken anlatılar üzerinde durulacaktır. 26 ve 27 paragraflarda Trimalchio karakteri ilk kez ortaya çıkar, yazarın yeni karakteri pohpohlayarak anlatması, ihtiyacını gümüş bir lazımlıkta giderdiğini, azıcık suyla yıkadığı ellerini köle çocukların saçlarında kuruttuğunu anlatması karakteri daha canlı ve ilgi çekici kılmak içindir. 28. Paragrafta masörlerinin Falernum şarabı içtiğinden ve sunu olarak yere döktüklerinden söz etmesi ise dikkatleri doğrudan bu konuya çeker, çünkü adı geçen şarap oldukça ünlü ve pahalıdır. ${ }^{75}$ Burada yazar pahalı şarabı masörlerin kadehine koyarak okuyucunun dikkatini çekmeye çalışır, ayrıca yoksul adama zengin şarabı içirerek bir tezat oluşturur. Yine aynı paragrafta Enclopius ile arkadaşları Trimalchio'nun evine girerken bir bekçi ile karşılaşırlar, kapıdaki bekçi gümüş bir kapta bezelye ayıklamaktadır, bu küçük bilgi bizi iki farklı noktaya götürebilir, ilki bezelye mayıs sonu-haziran başlarında hasat edildiğine göre yemek de olsa olsa bu aylarda bir yerde düzenlenmiş olmalıdır, bu süre en fazla temmuz ayına kadar uzatılabilir. İkincisi bu denli ucuz bir besinin gümüş bir kapta ayıklanmasıdır, yazar tıpk1 masörlerin en kaliteli şaraptan içmesi gibi burada da bir tezat oluşturuyor. Yoksul ile varlıklı arasındaki bu tezat göndermeleri romanın başka bölümlerine de yansıtılmıştır.

31. paragrafta konuklar yemek odasına girerler, daha girişte el ve ayaklarına buzlu sular dökülür ve bakım yapılır, yukarıda yemeğin bezelye hasadı yapılan aylarda yani yaz başında düzenlendiğini söylemiştik, yazar Trimalchio'nun evinde bu mevsimde buz bulunduğunu dile getirerek yeniden bir tezata başvuruyor. Tabii ki varlıklı kesimin yaz aylarında kullanmak amaciyla kuyularda kar biriktirdiği biliniyor, yine de Roma'da yaz aylarında düzenlenen bir şölende en değerli şey kar, buz veya soğuk sudur. Aynı paragrafın devamında konuklara koca bir tabağın içinde Korinthos sıpası sunuluyor, sıpanın sırtında bir semer, semerin bir gözünde siyah, ötekinde yeşil zeytin var, tepsinin kenarlarında da bal

\footnotetext{
72 Pertonius, Satyricon, 69-70.

73 Pertonius, Satyricon, 70.

74 Schmeling, 1996, s. 467.

75 Peter Bicknell, Opimian Bitter or 'Opimian' Wine, The American Journal of Philology, 98 / 3, 1968 , s. 347-49; Ali Güveloğlu, Antik Çağ Mutfak Sözlüğü, İstanbul, 2019º , s. 59.
} 
ve haşhaş tohumuna batırılmış kakırcalar. Yazar ilk yemek için oldukça sıra dışı bir seçim yapmış gibi görünüyor, zira alışkanlık olduğu üzere yemeğe yeşillik, marul, yumurta gibi hafif yemeklerle başlanır, ağır et yemekleri sonradan servis edilirdi. ${ }^{76}$ Yazar bu seçimiyle Trimalchio'yu adet bilmez, damak tadından yoksun ve geleneklere uymayan bir barbar gibi gösteriyor. Bu görgüsüzlügü gümüş bir kürdanla dişini karıştırdığ 1 ve elinde kristal zarlarla oyun oynadığı bir başka anlatılarda da kendini gösteriyordu. ${ }^{77}$ Aslında Petronius teatral bir sahnede resmettiği Enclopius, Ascyltus ve Trimalchio karakterleri üzerinden kendi döneminin sosyal ve dini gruplarını, eğitimsiz kesimini eleștirmenin bir yolunu bulmuştur demek hiç te yanıltıcı olmaz. ${ }^{78}$

34. paragrafta bir anlatıda konuklara Falernum şarabı ikram edildiği söylenir, şarap ağızları alçıyla kapatılmış camdan amphoralarla getirilmiştir yemek odasına. Trimalchio bu noktada söz alır ve konuklarına son derece kaliteli bir şarap ikram ettiğini, oysa bir gün önceki davette çok daha önemli konukları olmasına karşın daha düşük kaliteli bir şarap sunduğunu söyler. Konuşmanın devamında içtikleri şarabın Opimius'un ${ }^{79}$ consullük yaptığı yıldan kaldığını ve yüz yıldan daha uzun süre bekletildiğini söyleyip bu süreyi insan hayatıyla kıyaslar, ardından da insan ömrünün ne kadar kısa olduğuna vurgu yapar ${ }^{80}$ Trimalchio bu kadarıyla yetinmez, daha onun sözleri biter bitmez bir köle bu iş için yapıldığ1 belli olan gümüş bir iskelet getirip ortada dolaştırdıktan sonra masanın üzerine bırakır, ev sahibi vurgusunu biraz daha pekiştirmek için:

"Ey zavallı bizler, nasıl da bir hiçtir,

insan denen yaratık tepeden tırnă̆a!

Topumuz bunun gibi olacağız,

yeraltı tanrisı alınca bizi yanina.

Öyleyse yaşamaya bakalım,

keyfimiz yerinde oldukça. "81 (F. Gül Özaktürk’ün çevirisi)

şeklinde bir şiir okur. Böylece insanoğlunun yaşamının kısalığı vurgulanırken Trimalchio hedonist bir yaklaşım da sergiler. Bu anlatıyla Trimalchio bir kez daha tezata başvurmuş, insan hayatıyla şarabın ömrünü kıyaslamıştır. Ev sahibinin bilgeliği zenginliğiyle eş orantılı değildir, pek bilgili olmamasına karşın bir filozof gibi konuşmaya çalışır, ancak bu çabası boşa çıkar. ${ }^{82}$ Başka bir anlatıda sesi berbat olmasına karşın Menecrates'ten şarkı okumaya yeltenir.

\footnotetext{
76 Güveloğlu, 2018, 33 vd.

77 Petronius, Satyricon, 33.

78 Panayotakis, 2009, s. 48.

79 Opimius döneminde üretilen Falernum Şarabı hakkında bkz. Bicknell, 1968, s. 347 vd; ayrıca bkz. Güveloğlu, 2018, s. 122.

80 Söylediğine bakılırsa Trimalchio’nun konuklarına sunduğu şarap yaklaşık 170 yıllık olmalı. Bkz. Andrew Dalby, The Satyrica Concluded, Gastronomica, 5/4, 2005, s. 63 vd.

81 Petronius, Satyricon, 34.

82 Petronius, Satyricon, 56; ayrica bkz. Roland Mayer, Sleeping with the Enemy: Satire and Philosophy, The Cambridge Companion to Roman Satire, Ed. Kirk Freudenburg, UK, 2005, s. 146.
} 
Yazar Trimalchio'yu sonradan zengin olmuş bir azatlı olarak resmeder, eskiden çok fakirken girişimciliği sayesinde edindiği zenginlik sayesinde oldukça popüler bir kişilik haline dönmüsstür. Enclopius yemeğe ara verip yanında oturan adamla sohbet etmeye başladığı sırada buna benzer başka öykülerle karşılaşır. Bunlardan biri Gaius Pompeius Diogenes'tir, o da tıpk1 Trimalchio gibi bir azatlı iken sonradan zengin olmuştur, bu adamın yüzsüzlügü ve her şeyi kendine yontma alışkanlığ sohbet sırasında eleştiri konusu olmuştur. Romanda bu karakterin tam tersinin de bulunması ilgi çekicidir, Enclopius ve sohbet arkadaş1 eskiden zenginken sonradan fakir durumuna düşen başka bir adamdan söz etmeye başlarlar, yazar açık açık bu adamın "iyi bir insan" olduğunu dile getirir, işleri ters gitmeye başladığı için bütün mal varlığını kaybetmiştir, anlaşıldığı kadarıyla bunca badire atlatmış olmasına karşın insanlık erdemi hala onunla birliktedir. ${ }^{83}$ Yazar burada insan yaşantısından örnekler vererek bir tezat oluşturur ve hayat tarzlarının her zaman değişmeye açık, karakterin ise kalıcı olduğunu belirtir.

Cena Trimalchionis'te yemekler biçim bakımından farklılıklar gösterir. Mesela un ve yağ karışımından yapılmış tavus kuşu yumurtaları tavuk maketlerinin altına yerleştirilir, bu işlem konukları şaşırtmaya yetmiştir, çünkü Enclopius bir ara kendi yumurtasından civciv çıkacağını düşünür. ${ }^{84}$ Konuklara gerçek yumurta ikram etmek yalnızca lezzet açısından değerli olurken biçim üzerindeki değişiklik hem heyecan hem de lezzet sunar. Başka bir yemekte de bütün olarak pişirilmiş dişi bir domuzun cinsiyetini belli etmek için yavru domuzlar biçiminde ekmekler yaptırmıştır. ${ }^{85}$ Yine domuz rahminden yapılmış balık, etin farklı bölümlerinden yapılmış üveyik, kaz gibi kuş formları da yazarın yaratıcılığı ve yemeğin biçimleri üzerinde yapılmış oynamalardandır. ${ }^{86}$ Yazar simgeleri gerçek gibi göstermekten zevk alıyor gibi görünüyor. Enclopius ve arkadaşları yemek odasına gelirken ve hatta yemek sonunda hep birlikte hamamdan sıvışırken duvara çizilmiş resimdeki kocaman bir köpeği görüp korkarlar, hatta anlatıya göre Enclopius neredeyse düşüp bacağını kıracakmış, kaçış sırasında da gerçeği bilmelerine karşın sarhoşluğun verdiği yanılsamayla duvardaki resmi bir kez daha gerçek sanmaktan kurtulamamışlardır. ${ }^{87}$

Anlatıda dikkat çeken unsurlardan biri de tıbbi literatürden bilgiler içermesidir. Yukarıda Trimalchio'nun bir ara yemek odasını terk ettiğinden söz etmiştik, 47 paragrafla birlikte yeniden tricliniuma dönen Trimalchio dışarıda ihtiyaç giderdiğini ima eder. Ardından da bir süredir bağırsaklarının tıkalı olduğunu ancak hekimin önerisiyle sirkede bekletilmiş nar kabuğu ve çam reçinesi tükettiğini, bu karışımın şimdilik işe yaradığını dile getirir ${ }^{88} \mathrm{Bu}$ öneri tesadüfi değildir, yukarıda birkaç kez sürekli ağır et yemekleri servis edildiğinden söz etmiştik, Antik Çağ hekimleri bu tarz bir beslenmenin bağırsakları tıkayıcı etki göstereceği yönünde hem fikirdirler. Petronius da bu gerçeği romanına yansıtarak kahramanını üstü kapalı bir şekilde eleştirir. Dahası hekimlerin önerdiğini Literature, Ed. S. Harrison, UK. 2005, s. 391-92.

85 Petronius, Satyricon, 40.

86 Petronius, Satyricon, 70.

87 Petronius, Satyricon, 29, hamamdan kaçış sırasında yeniden korkmaları için bkz. 72.

88 Petronius, Satyricon, 47. 
söylediği nar kabuğu ve çam reçinesi daha önce Hippokrates, Dioskorides, Galenos ve Cato tarafından da aynı amaçlar doğrultusunda önerilmişti. ${ }^{89}$ Trimalchio daha sonra 56 numaralı paragraftaki bir konuşmasında hekimliğin en zor mesleklerden biri olduğunu dile getirir ve mide rahatsızlıklarına karşı hekimlerin kendisine dereotu suyu içirdiklerinden söz eder. Onun bu önerisinin de Eski Yunan'dan Roma'ya geçmiş olan hekimlik uygulamalarıyla uyumlu olduğu söylenebilir. ${ }^{90}$ elbette her zaman mide ve bağırsak hareketlerinden şikayetçi olması beslenme düzeninin ete dayalı olmasıyla açıklanabilir ve yazar bu ayrıntıyı gözden kaçırmamıştır.

Yukarıda Trimalchio karakterinin imparator Nero'yu anımsattığını, hatta bizzat onu eleştirmek için yaratılmış olabileceğini söyleyen araştırmacılar bulunduğunu dile getirmiştik. Bu tezi savunanların elindeki en önemli gösterge Suetonius'un anlatısındaki Nero'nun Domus Aurea'sındaki (Altın Ev) yemek odası (triclinium) ile Trimalchio'nun yemek odası arasındaki benzerliklerdir. Suetonius'un anlatısındaki evin yemek odas1 altın ve mücevherlerle kaplanmış ve son derece gösterişli dizayn edilmiştir, ${ }^{91}$ tarihçiler ve arkeologlar bu evin gerçekten var olup olmadığ konusunu bir türlü netleştirememiş olsa $\mathrm{da}^{92}$ anlatıdaki zenginlikle Trimalchio'nun yemek odasında konuklarına sunduğu zenginlik benzerlik gösterir. Daha önemlisi Nero'nun yemek odasının dönen tavanından konukların üzerine serpilen çiçek kokularıyla ${ }^{93}$ Trimalchio'nun yemek odasının tavanından sarkan çemberin etrafındaki koku şişeleri ve altın çelenkler birbirleriyle özdeş gibi görünür. ${ }^{94} \mathrm{Bu}$ kapsamda Cena Trimalchionis' in dönemin sıra dişı alışkanlıklarına bir eleştiri getirdiği doğrulanmış olur.

\section{Değerlendirme}

Cena Trimalchionis'i tarihsel açıdan incelemek zordur. Çünkü, yazar neyi-kimi anlattığını açıkça belirtmez, karakter kurgulamalarının gerçekçi mi, yoksa eleştirel mi olduğunu belirtmez, yine de konuklara sunulan yemeklerin tamamen kurgusal olduğu bellidir, çünkü hiçbiri arbiter elegantiae unvanını almış bir yazarın tercih edeceği türden değildir. Biraz daha derinlikli incelendiğinde yazarın yemek formlarında değişiklikler yaptığı da görülür, birçok noktada yemek göründüğünden farklı bir şeydir aslında, yumurta formundaki şey yumurta değildir, kaz formunda tabakta duran şey aslında domuz etinden yapılmıştır ve daha niceleri ile konukların görsel dünyası ile damak tadı arasında ayrı katmanlar oluşturulur. Romandaki önemli ayrımlardan biri de tezatlık ilkesidir köle-

89 Hippokrates’in nar kabuğu önerisi için bkz. Hippokrates, Epidemiae, II. 84, Çev. W. D. Smith, Cambridge vd., 1994; Dioskorides'in çam reçinesi önerisi için bkz. Dioskorides, De Materia Medica, I. 101. 1, Çev. Lily Y. Beck, 2005, Olms vd.; Galenos'un nar kabuğu önerisi için bkz. Galenos, Alimentarum Facultatibus, II. 604, Çev. M. Grant, 2000, USA; Cato'nun önerisi için bkz. Cato, De Agricultura, CXXVI, Çev. W. D. Hooper- H. B. Ash, Cambridge vd., 1935; ayrıca bkz, Güveloğlu 2018, s. 219.

$90 \quad$ Bkz. Güveloğlu, 2018, s. 194-204.

91 Suetonius, Nero, XXXI.

$92 \mathrm{Bu}$ konuda sürdürülen çalışmalarla ilgili bilgi için bkz. P. Gregory Warden, The Domus Aurea Reconsidered, The Journal of Architectural Historians, 40 / 4, 1981, s. 271 vd., arıca bkz. Michael Sommer, The Complete Romam Emperor, London, 2010, s. 86 vd.

93 Suetonius, Nero, XXXI; ayrıca bkz. Güveloğlu, 2014, s. 135.

94 Petronius, Satyricon, 60. 
özgür, varsıl-yoksul karakterlerin yaşam biçimleri arasında bir tezat oluşturulmuştur. Yoksul köleler en pahalı şaraptan içer, eskiden varsıl olan yoksula, yoksul olan varsıla dönüşür, ancak yine de karakterleri değişmez, sonradan zenginleşen eski yoksullar hala aç gözlü ve bilgisiz-görgüsüz karakterler olarak kalırlar. Roman farklı açılardan da ele alınabilir, örneğin Korinthos malı tabak çanaklardan, Attika balından, Hindistan'da yetişen mantarlardan, çeşitli takı-yün ve entariden söz ederek M.S. I. yüzyıl emtiası hakkında önemli bilgiler verebilir, ancak şölende sunulan yemekler hakkında kesinlikle eleştirel bir yaklaşım sergilenmiştir.

Araştırmacılar zengin azatlı Trimalchionis'in aslında Roma imparatoru Nero'yu temsil ettiği fikrindedir. Ancak imparatoru üstü kapalı bile olsa bu denli ağır biçimde eleştirmek öyle kolay bir şey değildir, öte yandan Nero'nun damak tadı Trimalchio'nunki kadar kötü değildir, hatta ilk başlarda onun şölenleri oldukça tutumludur, gerçi sonradan Trimalchio'nunki gibi oldukça masraflı ve gösterişli yemekler düzenlemiştir ama son yıllarında elde ettiği gücü ve dilediğini dilediği zaman ölüme gönderebilen kişiliği yüzünden hiçbir yazar onu Trimalchio ile kıyaslamaya veya eleştirmeye cesaret edemez. ${ }^{95}$ Metin tarihsel anlamda ciddiye alınacak bilgiler üretmese de günümüzde Roma dönemi yemek alışkanlıkları denince akla gelen ilk metin olma durumundadır. Tahmin edilebileceği üzere bu özelliğini Federico Fellini'nin 1969 yapımı Satyricon adlı filmindeki şölen sahnesine borçludur. Roma yemek düzeni hakkında derinlemesine bilgi veren araştırmalar olmasına karşın bir filmin bu denli etkili olması ise görsel sanatların etkinlik düzeyinin yüksek olmasıyla açıklanabilir.

Ne Cena Trimalchionis ne de Satyricon'un sözettikleribunlarla sınırlı değildir, aşçıların meziyetleri, yemek sunumunda kullanılan kap-kacak, kölelerin konuklarla sohbetleri, köle azat etme gösterileri, akrobat ve müzisyenlerin şovları ayrı ayrı ele alınabilecek konulardır. Hatta şölen dışında kalan kısımda Enclopius ve arkadaşlarının başlarından geçen başka türlü maceralar da ayrı inceleme konusu olabilir. Biz burada ilgi alanımız kapsamında şölende sunulan yemekleri ele almayı amaçladığımız için incelememizi bu noktada tamamlıyoruz.

\section{Bibliyografya}

Ali Güveloğlu, İmparator Sofraları, Mediterranean Journal of Humanities, IV / 2, 2014, s. 131-140.

Ali Güveloğlu, Antik Çăg’da Beslenme ve Damak Tadı, İstanbul, 2018.

Ali Güveloğlu, Antik Çağ'ın Damak Tadı Düşkünü Yazarları, Tarih ve Gelecek Dergisi, 5 / 2, 2019ª , s. 256-272.

Ali Güveloğlu, Antik Çăg Mutfak Sözlüğü, İstanbul, 2019².

Andrew Dalby, The Satyrica Concluded, Gastronomica, 5 / 4, 2005, s. 60-72.

Andrew Dalby, Empire of Pleasure, 2009, London.

95 Nero’nun damak tadı alışkanlıkları, şölenlerde tutumlu davranması ile ilgili olarak bkz. Güveloğlu, 2014, s. 135. 
Athenaios, Deipnosophistai (The Learned Banqueters), Çev. S. D. Olson, Cambridge vd., 2016.

Bret Boyce, The Language of the Freedmen in Petronius' Cena Trimalchionis, Leiden, 1991.

Catherine Connors, Petronius The Poet, Cambridge, 1998.

Catherine Connors, Arbitrium and verse in the Satyrica and in 'Petronius redivivus', Latin Fiction: The Latin Novel in Context, Ed. Heinz Hofmann, London-New York, 2005, s. 54-65.

Cato, De Agricultura (On Agriculture), Çev. W. D. Hooper- H. B. Ash, Cambridge vd., 1934.

Costas Panayotakis, Petronius and the Roman Literary Tradition, Petronius A Handbook, Eds. Jonathan R. W. Prag-Ian D. Repath, UK. 2009, s. 48-64.

Dioskorides, De Materia Medica, Çev. Lily Y. Beck, 2005, Olms vd.

Galenos, Alimentarum Facultatibus (On the Natural Faculties), Çev. M. Grant, 2000, USA

Graham Anderson, The Novella in Petronius, Latin Fiction: The Latin Novel in Context, Ed. Heinz Hofmann, London-New York, 2005, s. 44-53. 108.

Edward Champlin, Nero Reconsidered, New England Rewiew, 19 / 2, 1998, s. 97 -

Edward Courtney, A Companion to Petronius, Oxford, 2003.

Emily Gowers, The Loaded Table: Representations of Food in Roman Literature, Oxford, 1993.

F. Gül Özaktürk, Satyricon, Ankara, 2003.

Galenos, Alimentarum Facultatibus (Natural Faculties), Çev. A. J. Brock, Cambridge vd., 1979.

Gareth Schmeling, The Satyrica of Petronius, The Novel in the Ancient World, Ed. G. Schmeling, Leiden-New York-Köln, 1996, s. 457-490.

Gareth Schmeling, Petronius and the Satyrica, Latin Fiction: The Latin Novel in Context, Ed. Heinz Hofmann, London-New York, 2005, s. 19-31.

Henry T. Rowel, The Gladiator Petraites and the Date of Satyricon, Transactions and Proceedings of the American Philological Association, 89, 1958, s. 14-24.

Hippokrates, Epidemiae (Epidemics I-II), Çev. W. D. Smith, Cambridge vd., 1994.

Horatius, Satire II (İambus'lar, Lirik Şiirler, Satura'lar, Mektup'lar), Çev. Türkan Uzel, Ankara, 1994, s. 209-212.

John Bodel, The Cena Trimalchionis, Latin Fiction: The Latin Novel in Context, Ed. Heinz Hofmann, London-New York, 2005, s. 32-43.

Jonathan R. W. Prag-Ian D. Repath (Eds.), Petronius A Handbook, UK. 2009. 
J. R. Morgan, Petronius and Greek Literature, Petronius A Handbook, Eds. Jonathan R. W. Prag-Ian D. Repath, UK. 2009, s. 17-47.

Kenneth F. C. Rose, The Date and the Author of the Satyricon, Netherlands, 1971.

Michael Sommer, The Complete Romam Emperor, London, 2010.

Müzehher Erim, Latin Edebiyatı, İstanbul, 1987.

Nail W. Slater, Nero's Masks, The Classical World, 90 /1, 1996, s. 33- 40.

Nail W. Slater, Reading the Satyrica, Petronius A Handbook, Eds. Jonathan R. W. Prag-Ian D. Repath, UK. 2009, s. 16-31.

P. Gregory Warden, The Domus Aurea Reconsidered, The Journal of Architectural Historians, 40 / 4, 1981, s. 271-78.

Peter Bicknell, Opimian Bitter or "Opimian" Wine, The American Journal of Philology, 98 / 3, 1968, s. 347-49.

Petronius, Satyricon, Çev. W. H. D. Rouse, Cambridge vd., 1913.

Petronius, Satyricon, Çev. F. Gül Özaktürk, Ankara, 2003.

Plinius, Historia Naturalis (Natural History), Çev. D. E. Eichholz, Cambridge vd., 2006.

Platon, Symposion (Şölen), Çev. Eyüp Çorakl1, İstanbul, 2007.

Plutarkhos, Moralia, Çev. H. Chernis, Ed. J. Henderson, Cambridge vd., 1976.

Randall Ganiban, Crime in Lucan and Status, Brill's Companion to Lucan, Ed. Paolo Asso, Lieden-Boston, 2011, s. 327-344.

Roland Mayer, Sleeping with the Enemy: Satire and Philosophy, The Cambridge Companion to Roman Satire, Ed. Kirk Freudenburg, UK, 2005, s. 146-59.

Seneca, Epistulae Morales (Ahlaki Mektuplar), Çev. T. Uzel. Ankara, 1992.

Stephen Harrison, The Novel, A Companion to Latin Literature, Ed. S. Harrison, UK. 2005, s. 213-222.

Suetonius, De Vita Duodecem Caesaribus (On İki Caesar'ın Yaşamı), Çev. G. Özaktürk- F. Telatar, Ankara, 2008.

Tacitus, Annales (The Annals), Çev. J. C. Yardley, Ed. A. A. Barrett, Oxford, 2008.

Theresa N. Koper, Nero, Seneca and Tigellinus, Historia: Zeitschrift für Alte Geschichte, 28 / 3, 1979, 346-57.

Thomas Habinek, Slavery and Class, A Companion to Latin Literature, Ed. S. Harrison, UK. 2005, s. 386-93.

Tim Whitmarsh, Narrative and Identity in the Ancient Greek Novel, Cambridge, 2011. 